\title{
A mobil információs társadalom kutatási programja
}

2001 elején meglepő eredményeket felvonultató kutatássorozat indult a Magyar Tudományos Akadémia Filozófiai Kutatóintézetének irányításával, melyeket eddig két kötetben tártak a nagyközönség elé. A kutatás a XXI. század kommunikációját vizsgálja filozófusok, pszichológusok, közgazdászok, tudománytörténészek, politológusok és nyelvészek bevonásával. A Nyíri Kristóf professzor által vezetett vizsgálódások arra keresnek választ, hogy az Internet és a mobil telefon egyre terjedő használata hogyan alakítja át az életet az egyén, illetve a társadalom szintjein.

\section{Szerzői információ:}

KISSNÉ SzEli KATALin három éve diplomázott az ELTE magyar-francia szakán. 1999-től a BME-UNESCO Információs Társadalom- és Trendkutató Központ (ITTK) munkatársa. Az Európai Unió ESIS (European Survey of Information Society) programjában a hazai információs társadalom projektek szemlézóje, a kérdőíves adatfeldolgozás vezetôje, illetve a promóciós jelentések szerzője. 2001 tavaszától az ITTK Kutatási Jelentés c. folyóiratának társszerkesztője, illetve novembertól az ITTK Privacy hírlevelének olvasószerkesztője.

Így hivatkozzon erre a cikkre:

Szeli Katalin. „A mobil információs társadalom kutatási programja”.

Információs Társadalom I, 1. szám (2001): 74-77. https://dx.doi.org/10.22503/inftars.I.2001.1.7

A folyóiratban közölt müvek

a Creative Commons Nevezd meg! - Ne add el! - Így add tovább! 4.0

Nemzetközi Licenc feltételeinek megfelelöen használhatók. 


\section{SzELI KATALIN}

\section{A MOBIL INFORMÁCIÓS TÁRSADALOM KUTATÁSI PROGRAMJA}

Nagyszabású, interdiszciplináris kutatási program vette kezdetét 2001 januárjában $A$ huszonegyedik század kommunikációja címmel. Az MTA Filozófiai Kutatóintézete által irányított és a Westel Rt. által támogatott kutatás első szakasza a mobil információs társadalom kérdéskörére összpontosított. Jelen öszszefoglalónk a kutatás decemberben lezárt második szakaszának eredményeit foglalja össze. A tudományos munka vezetôje Nyíri Kristóf, aki a kutatási program távlati céljaként az információs társadalom újabb, valóban korszerú elméletének kidolgozását jelölte meg. (Nyíri Kristóf kutatási programjáról további információ található: http://21.sz.phil-inst.hu )

A kutatássorozat hátterében az alapvető, manapság oly sokszor hangoztatott felismerés áll, hogy korunk modern kommunikációs technológiája- - az internet és a mobil telefónia - gyökeresen alakítja át a társadalmi mechanizmusokat: az egyének gondolkodását, viselkedését, kapcsolatrendszereit. A kutatók ezt a folyamatot elemzik a különféle társadalomtudományok - a kommunikációelmélet, a filozófia, a pszichológia, a szociológia, a közgazdaságtan, a nyelvészet, a politikaelmélet és a tudománytörténet - által kínált eszközökkel.

\section{Társadalmi átszervezôdések}

Heller Mária több gondolkodóval együtt arra hívja fel a figyelmet, hogy az új információs és kommunikációs eszközök - elsôsorban a mobiltelefon - radikálisan megváltoztatják a kommunikációs szituáció tér- és idôkorlátjait átalakítva a társadalom kommunikációs szokásait és mintáit. Hatásukra a nyilvánosság szerkezete is módosul, hiszen a köz- és a magánszféra határai elmosódnak, Előtérbe kerül az orális kommunikáció, amely az informális, beszélt nyelvi stílusok térnyerését segíti elő.

$\mathrm{Az}$ új technológiák elterjedése alapvetóen az emberi kapcsolatok javára válhatnak: megkönnyíti a személytelen, gyors kapcsolatok teremtését és a hosszú távú, tartalmas kapcsolatok fenntartását. Heller Mária, a demokrácia vonatkozásában a fejlődésnek kétféle lehetséges útját vázolja fel. A hálózati kommunikáció révén szerinte az információkhoz való korlátlan hozzáférés, a kölcsönösség lehetősége és a hatalmi csoportok többoldalú, nyilvános kontrollja egy globális demokratizálódás irányába vezethetnek. Azonban - lévén, hogy a hatalom az információs társadalomban az információ, a tudás birtokosainak kezében van -, társadalmi, illetve globális szintű egyenlőtlenségek (a digitális szakadék) alakulhatnak ki az új kommunikációs lehetőségekból kizártak és a hozzáférők között.

Ferencz Sándor az új demokrácia helyett a tudásesély fogalmát vezeti be, amellyel kapcsolatban rendkívül optimista módon vélekedik: karnyújtásnyira van tőlünk a mainál nagyságrendekkel fejlettebb multimedialitású mobil kommunikáció, s ennek tömeges felhasználása csupán a piaci igények kritikus tömegének megteremtésén múlik. Az infokommunikációs eszközök használatának, az adatok információvá és tudássá komponálásának készségszintű elsajátíttatásában pedig a közoktatástól remél segítséget.

A kommunikációs tér és idő, valamint a beszélő́k körének mérhetetlen kiterjesztésében, amely a folyamatos és ellenőrzött jelenlétet kényszeríti ránk, Fekete László inkább veszélyeket sejt. Az emberi kommunikációtól antropológiailag idegen a folyamatos elérhetőség állapota, a beszéd tér- és időhatárainak lebontása (köz- és magánszféra, munkaidő és szabadidő egybecsúszása), amelyhez az állandó készenléttel és a drasztikus rövidítésekkel, tömörítésekkel próbálunk alkalmazkodni, „de nem lehetnek illúzióink, ebben mindenki vesztésre áll”. A másik, fenyegető veszély a társadalom szintjén jelentkezik. A szerző nem osztja azok véleményét, akik a tömegmédiumok utáni korszak interaktivitást is lehetővé tévő és (elviekben) mindenki elótt nyitva álló kommunikációs technológiáitól az ideális társadalom utópiájának beteljesedését várják. A gépek behatolása a személyek közötti kommunikációba, a különféle akusztikus és vizuális jelek digitalizációja lehetővé tette a kommunikáció eddig elválasztott csatornáinak konvergenciáját amelynek következtében a beszélók identitása és a közöttük zajló kommunikáció a gép és irányítójának kontrollja alá került. A világban sorra találkozunk az ellenörzött társadalom megvalósítását célzó politikai törekvésekkel (a tartalom szürésével, a teljes körú, folyamatos adatgyújtéssel, bizonyos algoritmusok különleges védelmével és mások tiltásával...), amelyek Kafka és Orwell vízióit könynyen valósággá változtathatják, ha a polgárok nem lépnek fel a kommunikáció és az információ szabadságának védelmében. 


\section{Képi gondolkodás}

Fenti, borúlátó elgondolással szemben Benczik Vilmos - összhangban Nyíri Kristófnak a tanulmányokat bevezető gondolataival - inkább pozitív hatásúnak ítéli az új kommunikációs eszközök, kiemelten a mobiltelefon szerepét a mindennapjainkban. Hiszen az emberi érintkezés alapformája a közvetlen emberi kommunikáció, amelyben az ember valamennyi érzékszerve részt vesz. Ehhez minden eddigi kommunikációs technika közül a telefon áll a legközelebb, ezen belül is a mobiltelefon, amely nem köti helyhez, azaz kábelhez használóját. A telefonos kommunikáció a természetes kommunikációhoz képest, relativizálja a teret (nem ad támpontot arról, hogy közvetlen közelrổl vagy több ezer kilométerrốl érkezik a hívás) és az időt (telefonon időzónákat átlépve is lehet érintkezni).

A mobiltelefonnal járó folyamatos elérhetóség paradox módon egyszerre növeli és csökkenti személyes szabadságunkat, hiszen használata során nem kényszerülünk mozgásunk korlátozására, de birtokosa folyamatos közösségi ellenőrzés alatt áll. Benczik mindemellett a mobil kommunikáció fejlődésével járó lehetséges pozitívumokat emeli ki: a mobiltelefonnal elviekben megoldható a hanggal egyidejû́ képátvitel, ami a közvetlen emberi kommunikáció még teljesebb leképezése lenne. A szerző Nyíri véleményét osztva úgy látja, hogy - az írásbeliséget visszaszorító-egyfajta visszatérés figyelhető meg az ember eredeti természeti-társadalmi környezetéhez, a folyamatos, minden érzékszervet igénybe vevő, interaktív kommunikációhoz, melyet a tudomány másodlagos szóbeliségnek nevez. Benczik szerint a kommunikációs technológiák fejlődésének nincs másik alternatívája, hiszen - hosszabb távon az emberi természet nem viseli el tartósan a kommunikáció természetes formájának tartott közvetlen emberi kommunikációtól való eltávolodását.

A fent idézett gondolatokat Nyíri Kristóf azzal egészíti ki, hogy a mobil kommunikáció azért sem idegen az embertól, illetve lehetôséget ad a gyökerekhez való visszatérésre, mert alkalmas képi üzenetek továbbítására. A tudomány egyre inkább kezd visszatérni ahhoz a felfogáshoz, miszerint az emberi gondolkodás eredendően nem szónyelvi formában, hanem lelki képek közegében zajlik. A gondolatok közlésének így a puszta szónál megfelelőbb eszköze lehet a képpel kiegészített szó, vagy olykor a puszta kép is. ősi, mimetikus-vizuális kultúránkra a homo sapiens kialakulásával, majd az írásbeliséggel gazdag verbális kultúra épült. A mobiltelefonok elterjedt használatával most olyan új kommunikációs formák - a kijelzőn megjeleníthető, gyorsan befogadható, szituációreleváns információk továbbításával - vezethetőek be, amelyek valójában az ember eredendően képies gondolkodásának felelnek meg. Ha a mobil kommunikáció vizuális nyelvvel történő gazdagítására törekszünk, kettős feladatot kell megoldanunk: egyrészt egységes konvenciókat kell bevezetnünk, másrészt ki kell aknáznunk a képi hasonlóságban, mint természetes jelentésközvetítő elemben rejlő lehetőségeket. A filozófus a közeljövő megkerülhetetlen feladatának tekinti az animált ikonikus nyelvek kidolgozását, amely kiváltképpen alkalmas arra, hogy kis képernyő́n sok információt közöljön, és elkerülje az állóképpel járó többértelmúség veszélyét.

A felhasználók körében renkívül népszerú oplogókat bemutató összeállításában Nyírő András is a mobil kommunikációban egyre erőteljesebben jelenlévő képi aspektust hangsúlyozza - igaz, nem az információhordozás, hanem a múvészi kifejezésmód lehetőségeként. Az emberek szeretnék saját képükre formálni telefonjaikat, azonban a napi 60-80 (évi kb. 25 000) új oplogó alkotása a szerző szerint egy új vizuális népmüvészet megszületésére hívja fel figyelmünket. Az oplogó sem kivétel, a vizuális népmúvészetek kedvelik a nehéz, kényelmetlen felületeket, mint például a tojásfestés, a graffiti és a tetoválás. Mindháromból felbukkan számos motívum a oplogókban; az új múfaj divatjának ereje azon lesz majd mérhetô, hogy visszafelé mennyire érvényesül ez a hatás.

\section{Tudáskezelés}

Mester Béla a már idézett, korunkat a másodlagos szóbeliség világaként értelmező felfogással kapcsolatosan azt állítja, hogy ez az akusztikus beállítódás csak a felhasználói gondolkodásmódokra, a tömegkultúrára érvényes. A könyvkultúrában kialakult tudásszerkezet továbbra sem tünt el, hiszen maguknak a tartalmaknak a megfogalmazása és elemzése ma is a könyvlogika szerint történik. A társadalomtudomány a nem írott szövegeken alapuló kommunikáció folyamatának elemzésekor is - zárt határokkal rendelkező, meghatározott információtartalmú - dokumentumokat keres. Vitathatatlan, hogy ma már egy új típusú dokumentummal állunk szemben, amelyben egyenrangúan kapcsolódik össze szöveg, kép és hang, s sokkal közelebb áll az ember eredeti, mindennapi információszerzési struktúrájához. A szerző jóslata szerint a mobiltelefonnak az internethez képest nagyobb az esélye a tömegkultúrában kialakuló új szóbeliség integrálására és részint megteremtésére, hiszen lapfunkciója mindvégig az élö emberi beszéd közvetítése marad. Fontos megemlítenünk a telefonok kollektív használatát is (amikor a közösség tagjai felolvasnak egy SMS-t, megbeszélnek egy minden- 
Csépe Valéria is fontosnak tekinti a társadalmi érvényesülésben a készségek szerepét, bár ő elsősorban az új technológiák készség szintû alkalmazására gondol. Kiemeli, hogy tapasztalatok is igazolják a még rugalmas gondolkodású fiatal generációk előnyös helyzetét ebben a versenyben. A mobiltelefonnak térés időkorlátokat lebontó tulajdonsága szerinte - a tárgykapcsolati erősség, az állandó elérhetőség és kapcsolatteremtés lehetősége okán - a függôség kialakulásával veszélyeztet. Félelmeit egy, fiatalok körében végzett kérdőíves felmérés eredményeivel is igazolta.

Buda Béla szerint jelenleg nem beszélhetünk mobil-addikcióról, bár a mobilhasználati módot helyenként lehet abúzusnak tekinteni (rengeteg idő eltöltése föleg fiataloknál SMS-küldéssel, feleslegesen gyakori, olykor már zaklató telefonálgatás). A pszichiáter meggyőződése, hogyha az idő mégsem ő́t igazolná, a mobil-hozzászokás jobb a kémiai anyagabúzusnál vagy más viselkedési abúzusoknál - tekintetbe véve óriási előnyeit az élet-, munka- és kapcsolatszervezésben, információszerzésben, segítségkérésben, stb.

\section{Nyelvhasználat}

A kutatók közül többen kitértek az internetnek és a mobiltelefonnak a nyelvhasználatban előidézett hatásaira. Ferencz Sándor az SMS-ek és az internetes portálok szövegeinek szúkös szövegszerúségére, feszességére és expresszivitására hívja fel a figyelmet, amely minden bizonnyal visszahat majd információs szokásainkra: szelekcióra, racionalizálásra, redundancia-mentességre, célszerú rövidítések használatára ösztönözhet. Kizárja azonban, hogy egy archaikus és nehézkes szöveges forma paradigmája kísértene; sokkal inkább úgy látja, hogy a rendkívül expresszív, szúkösen szöveges formák gondolkodási mechanizmusunk Nyíri szerint is alapvető vonását juttatják kifejezésre: gesztusok, képek és szimbólumok alkalmazásának igényét. Az SMS-ekben megfigyelhető rövidítéseket elemezve Csépe Valéria fontosabbnak tartja a nyelv elszegényedésénél a kreatív megoldások megszületését, és így egy, a normák által nem agyonszabályozott, egyszerủ, letisztult, új kommunikációs forma kialakulását. Sándor Klára nyelvész sem osztja a borúlátó jóslatokat, miszerint a modern kommunikációs eszközök kártékony hatást fognak gyakorolni a nyelvre. A nyelvi változások ugyanis sosem egyetlen tényezóhöz, hanem mindig tényezőegyüttesekhez köthetőek, ezért önmagában egy-egy technikai eszköz nem okozhat jelentős változásokat a nyelvben. Hellerhez hasonlóan ô is arra a megállapításra jut, hogy a nyelvhasználatban bekövetkezô lehetséges változások az írásbeliség trónfosztásához köthetốek. Itt nemcsak a Nyíri-féle értelemben vett természetes kommunikáció helyreállítódásáról van szó, ’hanem maga az írásbeliség is (köszönhetően az üzenetek gyors terjedésének) informálisabbá, természetesebbé, szóbelibb jellegưvé válik. Az állandó elérhetőség biztosítottságával lehetőség nyílik a jelentéktelennek tűnó, apró-cseprô ügyek megbeszélésére (e-mailben, SMS-ben, mobil beszélgetésben), amely hozzájárulhat a társas kapcsolthálózatok megerősödéséhez. Nyírinek a bevezetốben hangoztatott gondolataira rímelve Sándor is azt hangoztatja, hogy a nyelv hamarosan teljességében töltheti be eredeti funkcióját, ami nem az információcsere, hanem a társadalmi kohézió fenntartása.

A huszonegyedik század kommunikációja kutatási programjának eddigi eredményei fényében úgy túnik, hogy a modern kommunikáció eszközeinek mindennapjainkba való behatolása alapvetően a szellemi-társadalminyelvi értékek gazdagodását szolgálja. Nyíri szerint a mobil információs társadalomban egyfajta új otthonosság áll vissza, amelyben helyreáll az egység az egyén belsố szellemi rezdülései és külső közösségi környezete között.

IRODALOM

A XXI. sz. kommunikációja-konferencia (2001. május 29): MTA, Budapest. V. Roosevelt tér.

Nyíri Kristóf (2001): Mobil információs társadalom - tanulmánykötet, szerkesztette Nyíri Kristóf, MTA Filozófiai Kutatóintézete.

A XXI. századi kommunikáció új útjai-konferencia (2001. december 7): MTA, Budapest V. Roosevelt tér.

Nyíri Kristóf (2001): A XXI. századi kommunikáció új útjai-tanulmánykötet, szerkesztette Nyíri Kristóf; MTA Filozófiai Kutatóintézete. 